\title{
PLUTONIUM IN PLENTY
}

Tre fear that the proper exploitation of nuclear power for civil purposes would somehow assist the spread of nuclear weapons is not new, of course. Since the end of the Second World War, those nations able to supply nuclear equipment to others have done their best to see that no harm comes from this assistance. On the whole, the Soviet Union seems to have dealt with this problem by restricting severely its technical assistance to other countries. In the West, both the United States and the United Kingdom have taken the view that the development of civilian nuclear power throughout the world is to be encouraged, and have sought by means of international treaties to construct safeguards on the use made of the fissile material produced in their reactors. In the last four years there has been emerging the view that the International Atomic Energy Agency of the United Nations should eventually assume responsibility for the administration of safeguards on the use of plutonium, and there have been some encouraging experiments in the exercise of control of the operation of power reactors. In the article on page 1517, Leonard Beaton draws attention to the imperfections of the system of control now growing up, and in particular argues for a system in which the international agency would have the right and even the duty to own and physically to possess plutonium produced in reactors built by the advanced nations in countries outside their direct control. His argument should serve to emphasize the frailties of the present arrangements for safeguarding plutonium, and the urgent need that something should be done.

The most immediate and obdurate difficulty is well illustrated by the debates at Viemna in recent years on the construction of the safeguard system now being tried out. From the beginning it has been clear that developing countries will not willingly assent to a tacit recognition that non-nuclear powers and nuclear powers are dealt with differently. A system in which there is one law for the rich and one for the poor is never comfortable, for the poor at least. The safeguards which the international agency is now operating are in many ways influenced by the arguments of countries such as India that it would be inequitable to allow nuclear powers to accumulate plutonium as they wish and to apply the most stringent safeguards to the others. As things are, there is no doubt that tougher regulations at Vienna would only exacerbate the tendency of non-nuclear powers to become nuclear powers in their own right. It will be hard to get a safer restriction of the nuclear sovereignty of nonnuclear nations until the nuclear powers are prepared to give up something of their own.

In any case, the first need is to allow the International Atomic Energy Agency to win the confidence of member nations in its capacity to handle inter- national control systems. The present safeguards are a useful beginning even though they may be seriously incomplete, and there is of course no certainty that an international agency like that at Vienna would be able to handle all the serious problems of managing a substantial part of the world's stock of synthetic fissile material. It is better that it should first cut its teeth on something simple. It will be some time before the inspection of a few nominated reactors can be extended to cover the majority of those already built by nuclear powers in countries abroad. It is, however, worth remembering that even when that happy time arrives there will remain to be dealt with most of Mr. Beaton's catalogue of problems.

\section{WHO STAYS HOME?}

The House of Lords has come nearer to identifying the reasons why British scientists emigrate to the United States than many other institutions more adequately equipped to find an explanation. Several speakers in the debate on this subject the week before Christmas came out with the simple declaration that many of those who leave are tempted away by the many attributes of prosperity in the United States. Sometimes-let it be said-the prospect of more money to spend, not only on galvanometers and spectrophotometers, can be decisive. This is an accurate diagnosis, and one to be reckoned with. In some broad sense there has grown up a free international market in technical skill, and this extends to cover many developing countries as well as Western Europe and North America. Although personal gain is usually only a part of the reason why people move from one country to another, it is not discreditable. Emigrants to the United States from Western Europe have no more reason to be ashamed that they will bo better off than emigrants from India choosing to work in London rather than at home. But it is even more important that governments seeking to reduce the outward flow of skill should also reckon with the attractiveness of some of the side-effects of prosperity in a country like the United States. The process of operating a prosperous industrial society seems to create a climate of vigour, enterprise and daring. It is no wonder that emigrants are always saying that they are going abroad because they hope to do their work more efficiently, and faster.

Does it then follow that there is nothing to be done to halt or even control the steady westward migration of talented people from Europe? Does skill inexorably follow the GNP ? Must countries like Britain simply shrug their shoulders and hope that there will one day be a GNP which is big enough to make the tide flow 